\title{
Valorization of Rice Straw and Tofu Residue using Hermetia illucens to Produce Protein Rich Biomass and Organic Fertilizer
}

\author{
${ }^{1,2}$ Muhammad Yusuf Abduh, ${ }^{1}$ Nurhayati Buru Tarigan, ${ }^{1}$ Asep Hidayat and ${ }^{1}$ Robert Manurung \\ ${ }^{1}$ School of Life Sciences and Technology, \\ ${ }^{2}$ Bioscience and Biotechnology Research Centre, Institut Teknologi Bandung, Jalan Ganesha 10, \\ Bandung 40132, Indonesia
}

Correspondence

M.Y. Abduh, School of Life Sciences and Technology, Institut Teknologi Bandung, Jalan Ganesha 10, Bandung 40132, Indonesia, Tel.: +62 $222511575 ;+62222534107$

Received: May 26, 2020

Accepted: June 15, 2020

Published online: March 25, 2021

\begin{abstract}
The aim of this study was to investigate the potential bioconversion of rice straw and tofu residue using larvae of Hermetia illucens assisted by microbes to produce protein-rich biomass and organic fertilizer. Larvae of Hermetia illucens were cultivated in rearing containers $(25 \times 20 \mathrm{~cm})$ with three different types of substrate containing rice straw, tofu residue and solution containing consortium of microbes. The rice straw used in this study contains $22.1 \%$ hemicellulose, $30.3 \%$ cellulose, $8.0 \%$ lignin and $6.8 \%$ protein (weight basis) while the tofu residue contains $20.9 \%$ protein (weight basis). The substrate rate was set at $150 \mathrm{mg} / \mathrm{larva} /$ day and the ratio of rice straw: tofu residue was varied from 1:0 to 1:3. The highest prepupal biomass productivity of 179.8 $\mathrm{g} / \mathrm{m}^{2} /$ day on a dry weight basis with an assimilation efficiency of $21.5 \%$ and efficiency of conversion of digested substrate of $34.9 \%$ was obtained when the larvae were fed with rice straw and tofu residue (1:3) that had been pretreated with a solution containing $10^{7} \mathrm{cell} / \mathrm{mL}$ microbes. At this condition, the prepupal biomass has protein and fat content of 31.8 and $15.5 \%$ (weight basis), respectively. The cultivation residue contains a relative high amount of organic carbon (43-46\%) with $\mathrm{pH} 7.16-7.82$ and carbon to nitrogen ratio of 22-47 and a total macronutrient of 2.33-3.21\% and functional microbes of $2.0-4.5 \times 10^{8} \mathrm{CFU} / \mathrm{mL}$. The results highlight the potential of black soldier fly larvae as a bioconversion agent to convert agricultural waste into protein-rich biomass and organic fertilizer.
\end{abstract}

Keywords: Hermetia illucens, organic fertilizer, protein-rich biomass, rice straw, tofu residue

\section{INTRODUCTION}

Rice straw is a byproduct that can be obtained in abundance after the harvesting of Oryza sativa with approximately 932 million of rice straw that could be produced worldwide (Kadam et al., 2000). Rice straw mainly composed of cellulose (32-47\%), hemicellulose (19-27\%) and lignin (5-24\%) (Karimi et al., 2006;

(C) The Author(s) 2020. This article is licensed under a Creative Commons Attribution 4.0 International License, which permits use, sharing, adaptation, distribution and reproduction in any medium or format, as long as you give appropriate credit to the original author(s) and the source, provide a link to the Creative Commons license, and indicate if changes were made. The images or other third-party material in this article are included in the article's Creative Commons license, unless indicated otherwise in a credit line to the material. If material is not included in the article's Creative Commons license and your intended use is not permitted by statutory regulation or exceeds the permitted use, you will need to obtain permission directly from the copyright holder. To view a copy of this license, visit http://creativecommons.org/ licenses/by/4.0/. 
Wannapeera et al., 2008) and reported to have a high content of silicon dioxide (Kadam et al., 2000). Previous studies have reported that rice straw may be incorporated into the soil as an organic fertilizer or used as an animal feed but frequently rice straw is burned in the open air which results in air and water pollution as well as degradation of the soil (Marimuthu et al., 2002; Pan et al., 2015; Guzman et al., 2015).

Direct application of rice straw as an animal feed is limited by its high level of lignocellulosic content with low nitrogen, vitamin and mineral content that affects digestibility by ruminants (Trach, 1998). One of the strategies that can be used to reduce the lignocellulosic content in rice straw is with the help of Hermetia illucens or commonly known as black soldier fly that is known as a good bioconversion agent in organic waste management to produce protein and fat rich biomass that can be further valorized to produce animal feed (Müller et al., 2017; Abduh et al., 2017; Abduh et al., 2018; Gold et al., 2018). In addition, recent studies also reported that black soldier fly may find application for producing biodiesel (Nguyen et al., 2018), protein hydrolysate (Firmansyah and Abduh, 2019), bioactive substances (Müller et al., 2017) and fishmeal (Xiao et al., 2018; Belghit et al., 2019).

Many studies have reported that the protein and fat content of Black Soldier Fly Larvae (BSFL) lies in the range of $29-55$ and $19-39 \%$ on a weight basis which are highly influenced by the type of substrate and cultivation conditions such as feeding rate, temperature and light intensity (Diener et al., 2009; Manurung et al., 2016; Abduh et al., 2017; Harnden and Tomberlin, 2016; Abduh et al., 2018; Lalander et al., 2019). Manurung et al. (2016) had previously investigated the effect of feeding rate for the cultivation of BSFL using rice straw with a daily feeding rate of $200 \mathrm{mg} / \mathrm{larva} /$ day and reported a prepupal dry weight of $15.6 \mathrm{mg} / \mathrm{prepupa}$ with a development time of 39 days. However, the study did not analyze the composition of the harvested biomass and residue that remains after the cultivation period.

In another study by Zheng et al. (2012), a coconversion of rice straw and restaurant solid waste was carried out using BSFL and microbes for a cultivation period of 10 days. It was reported that the BSFL was able to digest cellulose, hemicellulose, lignin, protein and lipid for accumulation of biomass better with the aid of microbes as compared to without the help of microbes as in the research carried out by Manurung et al. (2016). Abduh et al. (2017) also investigated the effect of coconversion of rubber seeds with BSFL and microbes. The results showed that the percentage of conversion of feed into biomass $(7.5 \%)$ was highest when the substrate particularly rubber seeds were pre-treated with a consortium of microbes.

Cultivation of BSFL with various substrates such as manure as well as restaurant and agricultural waste have been investigated but systematic studies that explore the potential of rice straw and tofu residue as a substrate to produce protein rich biomass and organic fertilizer are still scarce. In this study, rice straw was mixed with tofu residue to increase the protein component of the substrate and later used as a substrate for the cultivation of BSFL. Tofu residue was chosen as a co-substrate in this study because it contains a considerable amount of protein (16.1 to $33.4 \%)$ and fat (0.8 to $22.3 \%)$ which can be obtained in abundance from tofu processing industries (Cheng et al., 2005; Li et al., 2013).

Hence, this study aims to investigate the effect of co-conversion of rice straw and tofu residue with a consortium of microbes on the growth of BSFL and composition of the harvested biomass and compared with the standard requirement for animal feed. In addition, the composition of the residual biomass was also investigated and compared with the standard requirement for organic fertilizer.

\section{MATERIALS AND METHODS}

Materials: Rice straw was obtained from local farmers in Sumedang, Indonesia whereas tofu residue was collected from local tofu factory in Bandung, Indonesia. Biotaff was purchased from PT Berlianplast (Jakarta, Indonesia) whereas black solder fly eggs were purchased from local farmers in Depok, Indonesia. Chicken meal and papaya were purchased from a local market in Bandung, Indonesia.

Preparation of substrate: Rice straw used in this study was crushed using a disc-mill up to 60 mesh. A solution containing consortium of microbes was prepared by dissolving one commercial tablet of Biotaff which contains $10^{11}$ bacterial cells with sterile aquades until a concentration of $10^{7}$ cell $/ \mathrm{mL}$ was obtained.

Cultivation of black soldier fly larvae: Five g of black soldier fly eggs were initially hatched in a container $(33 \times 25 \mathrm{~cm})$ and later reared with $2000 \mathrm{~g}$ chicken meal, $1000 \mathrm{~g}$ of papaya and $3 \mathrm{~L}$ of water. The container was covered with a mosquito mesh to prevent oviposition of other flies and then covered with a black lid. The 7 days hatched larvae were placed inside rearing containers $(25 \times 20 \mathrm{~cm})$ covered with a mosquito mesh. A larval density and feeding rate of 5 larvae $/ \mathrm{cm}^{2}$ and 150 $\mathrm{mg} /$ larva/day were applied in this study. The larvae were subjected into three different types of substrate; $\mathrm{P} 1$ ) rice straw pre-treated with a solution containing consortium of microbes, $\mathrm{P} 2)$ rice straw mixed tofu residue (1:3 mass ratio), P3) rice straw pre-treated with a solution containing consortium of microbes mixed with tofu residue (1:3 mass ratio). Water content in all substrates was set at $80 \%$. Cultivation of the larvae was carried out for 10 days followed by prepupae inactivation by drying the biomass at $103^{\circ} \mathrm{C}$ until the weight was constant. The weighed of the larvae was periodically measured during 
the cultivation period. The residue obtained after the cultivation was weighed before and after drying at $103^{\circ} \mathrm{C}$. The experiments were carried out at a temperature range of $28-30^{\circ} \mathrm{C}$ with the relative humidity lies in the range of $65-85 \%$.

Analytical methods: The lignocellulose content of the samples was analysed by using a hydrolysis method whereas the proximate analysis (protein, water, ash, fat and carbohydrate content) of the sample was analysed by using SNI-01-2891-1992 methods. The analysis was carried out at the Agricultural Industrial Technology Laboratory, University of Padjajaran, Jatinangor, Indonesia.

Data analysis: The effect of co-conversion of rice straw and tofu residue using BSFL and microbes was evaluated by calculating important conversion parameters particularly assimilation efficiency, efficiency of conversion of digested feed and substrate reduction rate which can be calculated by Eq. (1) to (3) as suggested by Abduh et al. (2017). The productivity of biomass can be calculated using Eq. (4):

$$
\begin{aligned}
& A E=\frac{D W_{f, o}-D W_{r}}{D W_{f, o}} \times 100 \% \\
& E C D \frac{D W_{r}}{D W_{f, o}-D W_{r}} \times 100 \% \\
& \text { Substrate reduction rate } \frac{A E}{t} \\
& \text { Biomass productivity }=\frac{D W_{b}}{A x t}
\end{aligned}
$$

where,

AE : Assimilation efficiency, \%

$\mathrm{DW}_{\mathrm{f}, \mathrm{o}}$ : Initial dry weight of feed, $\mathrm{g}$

$\mathrm{DW}_{\mathrm{r}}$ : Dry weight of residue

ECD : Efficiency of conversion of digested substrate, \% $\mathrm{DW}_{\mathrm{b}}$ : Dry weight of biomass, $\mathrm{g}$

$\mathrm{t} \quad$ : The cultivation period, day (equals to 10 days)

A : The cultivation area, $\mathrm{m}^{2}$ (equals to $0.05 \mathrm{~m}^{2}$ )

\section{RESULTS AND DISCUSSION}

Effect of substrate on the growth of black soldier fly larvae: This study has demonstrated the potential application of BSFL as a bioconversion agent to convert agricultural waste particularly rice straw and tofu residue to produce protein-rich biomass and organic fertilizer. The rice straw used in this study contains $22.1 \%$ hemicellulose, 30.3\% cellulose, $8.0 \%$ lignin and $6.8 \%$ protein while the tofu residue contains $20.9 \%$ protein (weight basis). Figure 1 shows the weight profile of larva fed with three different substrate composition; P1) rice straw pre-treated with a solution containing

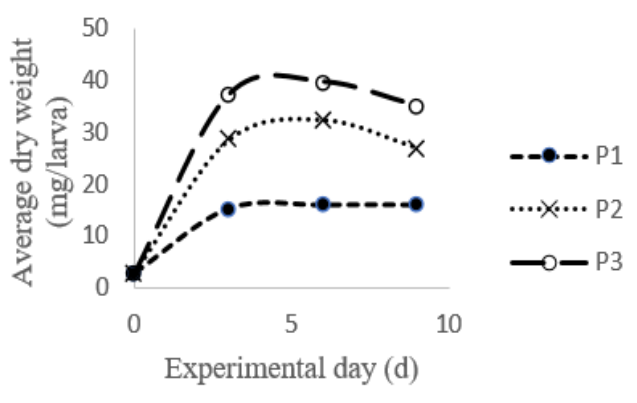

Fig. 1: Weight profile of larva fed with three different substrate compositions, P1) rice straw pre-treated with a solution containing consortium of microbes, P2) rice straw mixed tofu residue (1:3 mass ratio), $\mathrm{P} 3$ ) rice straw pretreated with a solution containing consortium of microbes mixed with tofu residue (1:3 mass ratio)

consortium of microbes, P2) rice straw mixed tofu residue (1:3 mass ratio), $\mathrm{P} 3)$ rice straw pre-treated with a solution containing consortium of microbes mixed with tofu residue (1:3 mass ratio). The results obtained showed that the BSFL was able to digest cellulose, hemicellulose and lignin contained in the rice straw for its accumulation of biomass with a maximum dry weight of $15.3 \mathrm{mg} /$ larva. This result resembles the previous finding by Manurung et al. (2016) that reported a maximum prepupal dry weight of $15.6 \mathrm{mg} / \mathrm{prepupa}$ but for a longer treatment period of 39 days.

When BSFL was fed using rice straw mixed with tofu residue, the maximum dry weight increased to 32.4 mg/larva with a higher maximum dry weight of 39.7 $\mathrm{mg}$ /larva was obtained when the substrate was pretreated with a consortium of microbes. As such indicates that consortium of microbes facilitates rapid bioconversion of the substrate into larval biomass. This is in agreement with the results obtained by Zheng et al. (2012) where BSFL was able to digest $65.5 \%$ of cellulose, $56.3 \%$ of hemicellulose, $8.8 \%$ of lignin, $91.6 \%$ of protein and 71.6 of lipid in the feed that consists of rice straw and restaurant solid waste for accumulation of biomass with a pre-treatment of the feed with consortium of microbes.

Figure 2 shows the proportion of substrate converted into prepupal biomass, used for metabolism of the larvae and remains as residual matter. A very big portion (68.8$74.8 \%$ ) of the substrate was categorized as residue, including faeces excreted by the BSFL or substrate that had not been consumed by the BSFL. Around 4.3-8.6\% of the substrate was consumed by the larvae and converted into prepupal biomass. Addition of tofu residue into rice straw that had been pre-treated with consortium of microbes $\left(10^{7}\right.$ cell $\left./ \mathrm{mL}\right)(\mathrm{P} 3)$ showed the highest conversion percentage of substrate into biomass $(8.6 \%)$ whereas the lowest value $(4.3 \%)$ was recorded when the larvae was only fed with rice straw $(\mathrm{P} 1)$. The percentage of substrate that was used by the larvae for 


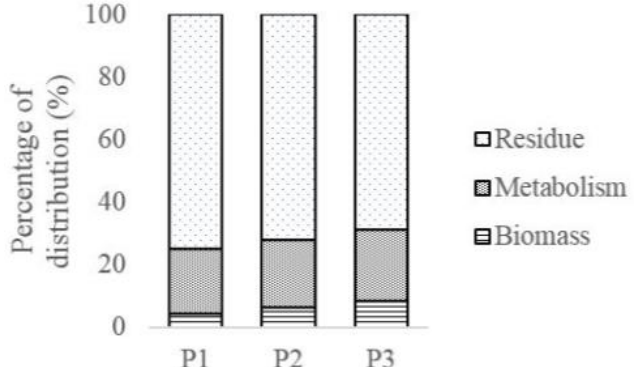

Fig. 2: Relative proportion of substrate converted into prepupal biomass, substrate used for metabolisms and substrate remains as residue, $\mathrm{P} 1$ ) rice straw pre-treated with a solution containing consortium of microbes, $\mathrm{P} 2$ ) rice straw mixed tofu residue (1:3 mass ratio), $\mathrm{P} 3$ ) rice straw pre-treated with a solution containing consortium of microbes mixed with tofu residue $(1: 3$ mass ratio)

metabolic needs was calculated from the difference percentage of residue and biomass which lies in the range of $20.93-22.53 \%$.

Table 1 shows the calculated assimilation efficiency, efficiency of conversion of digested substrate, substrate reduction rate and productivity of biomass. The assimilation efficiency of the BSFL lies in the range of $25.7-34.5 \%$ whereas the efficiency of conversion of digested feed varies from 11.9-21.9\%. Assimilation efficiency with a higher value means that the amount of initial substrate that remains as a residue is lower whereas a higher amount of efficiency of conversion indicates how efficient the larvae in converting the substrate into their biomass. In this study, the highest percentage of assimilation efficiency (34.5\%) and efficiency of conversion $(21.9 \%)$ were recorded when the larvae were fed with rice straw that had been pre-treated with a solution containing consortium of microbes and mixed with tofu residue (P3).

These values are higher than the maximum assimilation of $34.5 \%$ and conversion efficiency of $10.9 \%$ reported by Manurung et al. (2016) when the larvae were fed with only rice straw with a substrate reduction rate of 0.58 /day that is much lower than the maximum value obtained in this study (2.4/day). The biomass productivity obtained in this study (179.8 $\mathrm{g} / \mathrm{m}^{2} /$ day) exceeds the values reported by Abduh et al. (2018) and Diener et al. (2009) when the larvae were fed with trisperma seed $\left(123.4 \mathrm{~g} / \mathrm{m}^{2} /\right.$ day $)$ and chicken feed $\left(145 \mathrm{~g} . \mathrm{m}^{2} /\right.$ day $)$. As such indicates the advantage of coconversion with consortium of microbes to increase the ability of BSFL to convert organic waste to valuable bioproducts.

Composition of harvested biomass: After the cultivation of BSFL with rice straw and tofu residue, the prepupal biomass was analysed to determine the composition of protein, fat, carbohydrate, fibre as well as ash and the results are shown in Table 2. Initially, the substrate in P1 had a fat and protein content of 0.7 and $6.8 \%$ (weight basis), while $\mathrm{P} 2$ and $\mathrm{P} 3$ contain $3.9 \%$ of fat and $13.9 \%$ of protein (weight basis). After 10 days of treatment, the harvested biomass has a fat content in the range of 15.5 to $16.3 \%$ (weight basis); a tremendous increase of $297-2229 \%$ higher than the initial values in the substrate. The prepupae has a protein content of 31.8$34.4 \%$ (weight basis); a great increase of $129-406 \%$ than the initial values in the substrate. The protein content in P1 was higher than P3 and P3 because the harvested biomass was still in larval stage whereas for $\mathrm{P} 2$ and $\mathrm{P} 3$, the harvested biomass already reached prepupal stage.

Co-conversion of the substrate with BSFL and consortium of microbes produced prepupal biomass that have a very much higher protein and fat content than in the substrate. The protein and fat content in the prepupal biomass determined in this study are lower than those reported by Abduh et al. (2018) when the larvae were fed with trisperma seed $(45.1 \%$ for protein and $26.6 \%$ for fat). In another study, the protein and fat content reached up to 46.3 and $39.6 \%$ when the larvae were fed using rice straw mixed with restaurant solid waste (Zheng et al., 2012). Different amount of protein and fat content in the

Table 1: Assimilation efficiency, efficiency of conversion, waste reduction index and estimated productivity of prepupal biomass

\begin{tabular}{lllll}
\hline Substrate condition & Assimilation efficiency $(\%)$ & $\begin{array}{l}\text { Efficiency of conversion } \\
(\%)\end{array}$ & $\begin{array}{l}\text { Substrate reduction } \\
\text { rate/day }\end{array}$ & $\begin{array}{l}\text { Productivity of biomass } \\
\left(\mathrm{g} . \mathrm{m}^{2} / \text { day }\right)\end{array}$ \\
\hline P1* & 25.7 & 11.9 & 1.3 & 73.3 \\
P2* & 29.9 & 12.9 & 1.4 & 123.3 \\
P3* & 34.5 & 21.9 & 2.4 & 179.8 \\
\hline
\end{tabular}

*: P1) rice straw pre-treated with a solution containing consortium of microbes, P2) rice straw mixed tofu residue (1:3 mass ratio), P3) rice straw pre-treated with a solution containing consortium of microbes mixed with tofu residue (1:3 mass ratio)

Table 2: Composition of protein, fat, carbohydrate, fibre and ash content (weight basis) of harvested prepupal biomass at different cultivation conditions

\begin{tabular}{llllll}
\hline Substrate condition & Protein content (\%) & Fat content (\%) & Carbohydrate content (\%) & Fibre content (\%) & Ash content (\%) \\
\hline P1* & 34.4 & 16.3 & 17.1 & 21.1 & 10.1 \\
P2* & 32.1 & 16.1 & 14.2 & 24.7 & 10.4 \\
P3* & 31.8 & 15.5 & 10.4 & 29.7 & 10.2 \\
\hline
\end{tabular}

*: P1) rice straw pre-treated with a solution containing consortium of microbes, P2) rice straw mixed tofu residue (1:3 mass ratio), P3) rice straw pre-treated with a solution containing consortium of microbes mixed with tofu residue (1:3 mass ratio) 
Table 3: Properties of residual substrate remained after the cultivation of black soldier fly larvae

\begin{tabular}{|c|c|c|c|c|}
\hline Parameter & $\mathrm{P} 1 *$ & $\mathrm{P} 2 *$ & $\mathrm{P} 3 *$ & $\begin{array}{l}\text { Solid organic fertilizer } \\
\text { standard** }\end{array}$ \\
\hline C-organic (\%) & 46.25 & 43.45 & 43.05 & Min. 15 \\
\hline $\mathrm{C} / \mathrm{N}$ & 46.72 & 25.86 & 22.42 & $15-25$ \\
\hline $\mathrm{pH}$ & 7.53 & 7.82 & 7.16 & $4-9$ \\
\hline Macronutrient $(\%)$ & & & & Min. total of $\mathrm{N}+\mathrm{P}_{2} \mathrm{O}_{5}+\mathrm{K}_{2} \mathrm{O} 4 \%$ \\
\hline $\mathrm{N}$ & 0.99 & 1.68 & 1.92 & \\
\hline $\mathrm{P}_{2} \mathrm{O}_{5}$ & 0.13 & 0.21 & 0.18 & \\
\hline $\mathrm{K}_{2} \mathrm{O}$ & 1.21 & 1.29 & 1.11 & \\
\hline Functional microbes $* * *(\mathrm{CFU} / \mathrm{mL})$ & $3.7 \times 10^{8}$ & $4.5 \times 10^{8}$ & $2.0 \times 10^{8}$ & Min. $10^{3}$ \\
\hline
\end{tabular}

Table 4: Lignocellulose content (weight basis) of substrate before and after cultivation with black soldier fly larvae

\begin{tabular}{|c|c|c|c|}
\hline Substrate condition & Cellulose (\%) & Hemicellulose $(\%)$ & Lignin (\%) \\
\hline Rice straw & 30.28 & 22.14 & 7.93 \\
\hline $\mathrm{P} 1 *$ & 7.40 & 2.97 & 2.38 \\
\hline $\mathrm{P} 2 *$ & 7.15 & 1.40 & 6.23 \\
\hline P3* & 6.23 & 1.58 & 1.94 \\
\hline
\end{tabular}

*: P1) rice straw pre-treated with a solution containing consortium of microbes, P2) rice straw mixed tofu residue (1:3 mass ratio), P3) rice straw pre-treated with a solution containing consortium of microbes mixed with tofu residue (1:3 mass ratio)

harvested biomass obtained in this study may be due to lower initial fat and protein content in the substrate. In addition, the protein and fat content in the harvested biomass is highly influenced by the type of substrate used in the cultivation process, readily available digestive enzymes as well as the killing method of the prepupae (Kim et al., 2011; Gold et al., 2018; Caligiani et al., 2018; Lalander et al., 2019; Leni et al., 2019).

The protein and fat content of the prepupal biomass obtained in this study satisfy the specification of animal feed for chicken (minimum of $13.5 \%$ for protein; $7 \%$ for fat) as outlined by the Indonesian National Standard for protein (SNI 01-3929-2006) and fat (SNI 01-39092006). Hence, the prepupal biomass of BSF cultivated with the remaining biomass from rice straw mixed with tofu residue may be utilized for animal feed application.

Properties of residual substrate: The properties of the residual substrate remain after the cultivation of BSFL was analysed to investigate its potential to be valorised as solid organic fertilizers and the results are shown in Table 3. The $\mathrm{pH}$ of the residual substrate for all cultivation conditions is in the range of 7.2-7.8 which lies in the range of $\mathrm{pH} 4-9$ set by the Ministry of Agriculture of Indonesia. The C-organic of the residual substrate for all cultivation conditions lies in the range of $43-46.3 \%$ which is well above a minimum standard of $15 \%$. Nevertheless, only residual substrate obtained from $\mathrm{P} 3$ cultivation condition that had a $\mathrm{C} / \mathrm{N}$ ratio lies in a standard range of 15-25. The residual substrate had enough functional microbe $\left(2.0 \times 10^{8}-4.5 \times 10^{8} \mathrm{CFU} / \mathrm{mL}\right)$ but the minimum total of $\mathrm{N}, \mathrm{P}_{2} \mathrm{O}_{5}$ and $\mathrm{K}_{2} \mathrm{O}$ still less than the required value of $4 \%$.

Lignocellulose content of the residual substrate was also analysed and compared with the rice straw (Table 4). Initially the rice straw had a cellulose and hemicellulose content of 30.28 and $22.14 \%$ (weight basis). At the end of the cultivation period, the cellulose and hemicellulose content decreased around 75-79 and $86-92 \%$ for all treatments. The data indicates that BSFL was able to degrade cellulose and hemicellulose although without the addition of the consortium of microbes. As for lignin, the lignin content only decreased from 7.93 to $6.23 \%$ (weight basis) when the larvae were fed with rice straw mixed without tofu residue only (P2). When the substrate was pre-treated with a solution containing consortium of microbes $\left(10^{7}\right.$ cell $\left./ \mathrm{mL}\right)$, the lignin content decreased to $2.38 \%$ (P1) and $1.94 \%$ (P3) on a weight basis.

The residual substrate obtained after the cultivation period has a potential to be valorised as an organic fertilizer. For the case of when larvae were fed with rice straw mixed with tofu residue and pre-treated with consortium of microbes, the properties of the residual substrate satisfy all the requirements for a solid organic fertilizer set by the Ministry of Agriculture of Indonesia except for the total content of $\mathrm{N}, \mathrm{P}_{2} \mathrm{O}_{5}$ and $\mathrm{K}_{2} \mathrm{O}$ that should be at least $4 \%$. Hence, additional macronutrient needs to be added especially $\mathrm{P}_{2} \mathrm{O}_{5}$ for solid fertilizer application.

\section{CONCLUSION}

Bioconversion of rice straw and tofu residue using larvae of Hermetia illucens assisted by microbes to produce protein-rich biomass and organic fertilizer has been investigated. A biomass productivity of 179.8 $\mathrm{g} / \mathrm{m}^{2} /$ day on a dry basis with an assimilation efficiency of $21.5 \%$ and efficiency of conversion of digested feed $34.9 \%$ was obtained when black soldier fly larvae were fed with rice straw and tofu residue (1:3) that had been pre-treated with a solution containing $10^{7}$ cell $/ \mathrm{mL}$ microbes. At this condition, the prepupal biomass has a protein content of $31.8 \%$ and a fat content of $15.5 \%$ 
(weight basis). The cultivation residue contains a relative high amount of organic carbon with a carbon to nitrogen ratio of 22-47 and total macronutrient of 2.33-3.21\% and functional microbes of $2.0-4.5 \times 10^{8} \mathrm{CFU} / \mathrm{mL}$. The results highlight the potential of black soldier fly larvae as a bioconversion agent to convert agricultural waste into protein-rich biomass and organic fertilizer.

\section{ACKNOWLEDGMENT}

The work described in this study was funded by a research grant from Institut Teknologi Bandung (P3MI KK-ATB 2017).

\section{CONFLICT OF INTEREST}

Authors declare no conflict of interest.

\section{REFERENCES}

Abduh, M.Y., M. Jamilah, P. Istiandari, Syaripudin and R. Manurung, 2017. Bioconversion of rubber seeds to produce protein and oil-rich biomass using black soldier fly larva assisted by microbes. J. Entomol. Zool. Stud., 5(4): 591-597.

Abduh, M.Y., M.H. Nadia, Syaripudin, R. Manurung and R.E. Putra, 2018. Factors affecting the bioconversion of Philippine tung seed by black soldier fly larvae for the production of protein and oil-rich biomass. J. Asia-Pacific Entomol., 21(3): 836-842.

Belghit, I., N.S. Liland, P. Gjesdal, I. Biancarosa, E. Menchetti, Y. Li, R. Waagbø, Å. Krogdahl and E.J. Lock, 2019. Black soldier fly larvae meal can replace fish meal in diets of sea-water phase Atlantic salmon (Salmo salar). Aquaculture, 503: 609-619.

Caligiani, A., A. Marseglia, G. Leni, S. Baldassarre, L. Maistrello, A. Dossena and S. Sforza, 2018. Composition of black soldier fly prepupae and systematic approaches for extraction and fractionation of proteins, lipids and chitin. Food Res. Int., 105: 812-820.

Cheng, Y., N. Shimizu and T. Kimura, 2005. The viscoelastic properties of soybean curd (tofu) as affected by soymilk concentration and type of coagulant. Int. J. Food Sci. Tech., 40(4): 385-390.

Diener, S., C. Zurbrügg and K. Tockner, 2009. Conversion of organic material by black soldier fly larvae: Establishing optimal feeding rates. Waste Manage. Res., 27(6): 603-610.

Firmansyah, M. and M.Y. Abduh, 2019. Production of protein hydrolysate containing antioxidant activity from Hermetia illucens. Heliyon, 5: e02005.
Gold, M., J.K. Tomberlin, S. Diener, C. Zurbrügg and A. Mathys, 2018. Decomposition of biowaste macronutrients, microbes, and chemicals in black soldier fly larval treatment: A review. Waste Manage., 82: 302-318.

Guzman, A., A. Delvasto and V. Sanchez, 2015. Valorization of rice straw waste: An alternative ceramic raw material. Ceramica, 61(357): 126-136.

Harnden, L.M. and J.K. Tomberlin, 2016. Effects of temperature and diet on black soldier fly, Hermetia illucens (L.) (Diptera: Stratiomyidae), development. Forensic Sci. Int., 266: 109-116.

Kadam, K.L., L.H. Forest and W.A. Jacobson, 2000. Rice straw as a lignocellulosic resource: Collection, processing, transportation, and environmental aspects. Biomass Bioenerg., 18(5): 369-389.

Karimi, K., G. Emtiazi and M.J. Taherzadeh, 2006. Production of ethanol and mycelial biomass from rice straw hemicellulose hydrolyzate by Mucor indicus. Process. Biochem., 41: 653-658.

Kim, W., S. Bae, K. Park, S. Lee, Y. Choi, S. Han and Y. Koh, 2011. Biochemical characterization of digestive enzymes in the black soldier fly, Hermetia illucens (Diptera: Stratiomyidae). J. Asia-Pac. Entomol., 14: 11-14.

Lalander, C., S. Diener, C. Zurbrügg and B. Vinneras, 2019. Effects of feedstock on larval development and process efficiency in waste treatment with black soldier fly (Hermetia illucens). J. Clean. Prod., 208: 211-219.

Leni, G., A. Caligiani and S. Sforza, 2019. Killing method affects the browning and the quality of the protein fraction of black soldier fly (Hermetia illucens) prepupae: A metabolomics and proteomic insight. Food Res. Int., 115: 116-125.

Li, S., D. Zhu, K. Li, Y. Yang, Z. Lei and Z. Zhang, 2013. Soybean curd residue: Composition, utilization, and related limiting factors. ISRN Ind. Eng., 2013: 1-8.

Manurung, R., A. Supriatna, R.R. Esyanthi and R.E. Putra, 2016. Bioconversion of rice straw waste by black soldier fly larvae (Hermetia illucens L.): Optimal feed rate for biomass production. J. Entomol. Zool. Stud., 4(4): 1036-1041.

Marimuthu, S., P.T. Ramesh, A. Solaimalai, N. Ravisankar, S. Anbumani and C. Sivakumar, 2002. Management of rice residues for rice production-a review. Agric. Rev., 23: 165-174.

Müller, A., D. Wolf and H.O. Gutzeit, 2017. The black soldier fly, Hermetia illucens - a promising source for sustainable production of proteins, lipids and bioactive substances. Z. Naturforsch C, 72: 351-363. 
Nguyen, H.C., S.H. Liang, S.S. Chen, C.H. Su, J.H. Lin and C.C. Chien, 2018. Enzymatic production of biodiesel from insect fat using methyl acetate as an acyl acceptor: Optimization by using response surface methodology. Energ. Convers. Manage., 158: 168-175.

Pan, F., Y. Li, S.J. Chapman and H. Yao, 2015. Effect of rice straw application on microbial community and activity in paddy soil under different water status. Environ. Sci. Pollut. R., 23(6): 5941-5948.

Trach, N.X., 1998. The need for improved utilisation of rice straw as feed for ruminants in Vietnam: An overview. Livestock Res. Rural Dev., 10(2): 80-94.

Wannapeera, J., N. Worasuwannarak and S. Pipatmanomai, 2008. Product yields and characteristics of rice husk, rice straw and corncob during fast pyrolysis in a drop-tube/fixed-bed reactor. Songklanakarin J. Sci. Technol., 30: 393-404.
Xiao, X., P. Jin, L. Zheng, M. Cai, Z. Yu, J. Yu and J. Zhang, 2018. Effects of black soldier fly (Hermetia illucens) larvae meal protein as a fishmeal replacement on the growth and immune index of yellow catfish (Pelteobagrus fulvidraco). Aquac. Res., 49(4): 1569-1577.

Zheng, L., Y. Hou, W. Li, S. Yang, Q. Li and Z. Yu, 2012. Biodiesel production from rice straw and restaurant waste employing black soldier fly assisted by microbes. Energy, 47(1): 225-229. 